\title{
Introducing Jerusalem: Visiting Cards, Advertisements and Urban Identities at the Turn of the 2oth Century
}

\author{
Maria Chiara Rioli
}

Sources are neither open windows, as the positivists believe, nor fences obstructing vision, as the skeptics hold: if anything, we could compare them to distorting mirrors. ... [T] he projection of desire, without which there is no research, is not incompatible with the refutations inflicted by the principle of reality. ${ }^{1}$

In August 2013, during the renovation of the Franciscan Custody library, an Italian collector found an album containing around 1,500 visiting cards in a deposit of books that were to be thrown away. ${ }^{2}$ The carte da visita in this catalogue were issued by the Stamperia di Terra Santa ${ }^{3}$ and were printed from 1880 to the beginning of the twentieth century, although their production was continued by the Franciscan Printing Press (FPP) over the following decades. As this anecdote shows, Jerusalem's archives are everywhere: not only in the hands of institutions and archivists, but also in basements, attics, or stacks of volumes ready to be discarded.

The organization of labor inside the FPP sets the Franciscan Custody of the Holy Land ${ }^{4}$ within the larger context of political and economic connections, governed by systems of favors among families and religious groups, and an unstable balance of interests. We don't know how, or if, the clients of the press

1 Carlo Ginzburg, History, Rhetoric, and Proof (Hanover: University Press of New England, 1999), 25 .

2 The research for this chapter was conducted in close collaboration with Leyla Dakhli. I express my deep gratitude to this collector for allowing us to consult this album.

3 The Franciscan Printing Press (FPP) was referred to as the Stamperia and Tipografia due to the Italian prominence in the history of the Custody of the Holy Land.

4 For a bibliography of the history of the Franciscan presence in the Palestinian area and the FPP, see the contribution of Leyla Dakhli, "Men at Work: The Tipografia di Terra Santa, 18471930," in this volume, especially notes 1 and 3 .

(C) MARIA CHIARA RIOLI, 2018 | DOI:10.1163/9789004375741_005

This is an open access chapter distributed under the terms of the prevailing CC-BY-NC-ND License at the time of publication. 
perceived the rigid internal system of rules. What is evident from the registries is that the press had a wide range of buyers and clients.

In attempting to understand the external dimension of the FPP's activities, the collection of visiting cards, advertisements, and announcements issued by the friars' atelier is an extremely rich and prismatic source. Shortly after its opening in 1847, the publishing enterprise of Custody friars had expanded beyond the ecclesiastical community. It was attended by Ottoman officials from the most important institutions of the government and later by authorities of the British Mandate as well as by a constellation of private clients of different languages, religions, genders, and social and political status. ${ }^{5}$ The FPP established itself as a center of production of all kinds of printed signs for the city: posters, signs, billboards, visiting cards, programs, menus, directions for use, guides for travelers, etc. In its capacity as the source of much of the city's media, the Custody is a key resource for the study and understanding of Jerusalem's citadinité. It reveals the history of the city across many levels varying in scope and detail. From the operations itself, through the printing house and its network of clients and users, we ultimately see the extent of Custody's influence as evidenced by the papers themselves. Produced and printed in the Custody, they circulated throughout the streets, libraries, boutiques, hotels, and administrative centers of the city and beyond, thanks to the international network of the Franciscan order.

Printed materials other than books made up a large part of the friars' production. Paper sheets, envelopes, flower cards, postcards, sheet music, medical prescriptions, labels, announcements, programs for lotteries, plays or other performances, school reports, nationality certificates, travel plans, lodging tickets, railway timetables, and restaurant menus were issued daily, testifying to an intense flow of work. This list demonstrates how the FPP was not a traditional religious and confessional publisher: its many clients included secular people and institutions. Furthermore, the Franciscans worked for the Jerusalem government; the press produced for the municipality of Jerusalem printed statistics and registries, announcements, licenses, and regulations for the election of its members.

5 In 1865 the FPP printed the city's first hydraulic project, Relazione e progetto di condurre l'acqua del fonte-segnato all'altezza della porta Bab-el-Kalil, by Fra Remigio Buselli for Jerusalem governor Izzet Pasha. See Vincent Lemire, La soif de Jérusalem: essai d'hydrohistoire (1840-1948) (Paris: Publications de la Sorbonne, 2011), 240-47. 
As revealed by the registries collected by the Custody of the Holy Land's archives at St. Saviour's convent, ${ }^{6}$ during the last decades of the nineteenth and the first half of the twentieth centuries, some of the products most commonly ordered from the Franciscans were calling cards, trade cards, advertisements, greetings cards, and cards for announcements and invitations. A repertory of 1,485 pieces was collected in a catalogue named "Carte di visita avvisi ec. 1880," covering the period from 1880 to the first years of the new century, probably 1906 (fig. 2.1). ${ }^{7}$ No similar albums seem to be currently held in the Franciscan archives or in any other archive of the city. The precise use of this volume is unclear. Maybe it was a way to register the cards printed, to keep an exemplar that could be shown to new potential clients. The registries of the objects issued reveal that the album contains a large percentage of the cards printed at that time.

Calling cards, business cards, and trade cards accompanied social and economic relations from the eighteenth century onwards, reaching the peak of their popularity in the nineteenth century in Europe and in the United States, ${ }^{8}$ as well as in the Ottoman Empire, where they were called kart fizit. ${ }^{9}$ Calling

6 Historical Archive of the Custody of the Holy Land (ASCTS), Jerusalem, "Introito attivo" generale, 1: January 2-December 31, 1923; 2: January 2, 1924-September 30, 1931; 3: October 3 1931-December 1938; 4: January 1939-January 1945; "Introito attivo" oggetti stampati, 1:January 2, 1888-December 22, 1894; 2:January 12, 1895-February 6, 1909; "Introito passivo," 1: January 1900-December 1908; January 1919-December 1919; "Libri ed oggetti dati o stampati gratuitamente 1900-1908 coll'aggiunta solo l'anno 1919;" 2: January 4, 1909-December 30, 1918; January 1, 1920-December 26, 1931; 3: January 2, 1922-October 31, 1931; 4: November 2, 1931-January 4, 1938.

7 This catalogue, whose dimension is $26 \times 39 \mathrm{~cm}$, contains 112 pages. Cards are thickly attached horizontally and vertically in order to fill all the available space. They are numbered by hand until number 411. Some cards contain dates, as in the case of wedding cards and other announcements. As they were placed in chronological order, although not completely precise, the contemporary reader can retrace the periodization.

8 In the extensive bibliography, see at least William C. Darrah, Cartes de Visite in Nineteenth Century Photography (Gettysburg: W. C. Darrah, 1981); Robert Jay, The Trade Card in Nineteenth-Century America (Columbia: University of Missouri Press, 1987); Margaret E. Hale, "The Nineteenth-Century American Trade Card," Business History Review 74, no. 4 (2000); Geoffrey Batchen, "Dreams of Ordinary Life: Cartes-de-Visite and the Bourgeois Imagination," in Photography: Theoretical Snapshots, ed. Jonathan J. Long, Andrea Noble and Edward Welch (Abingdon: Routledge, 2009); Andrea L. Volpe, "Cartes de Visite Portrait Photographs and the Culture of Class Formation," in The Middling Sorts: Explorations in the History of the American Middle Class, ed. Burton J. Bledstein and Robert D. Johnston (London: Routledge, 2001).

9 As mentioned by Ami Ayalon about Haifa in Reading Palestine: Printing and Literacy, 19oo1948 (Austin: University of Texas Press, 2004), 59. 


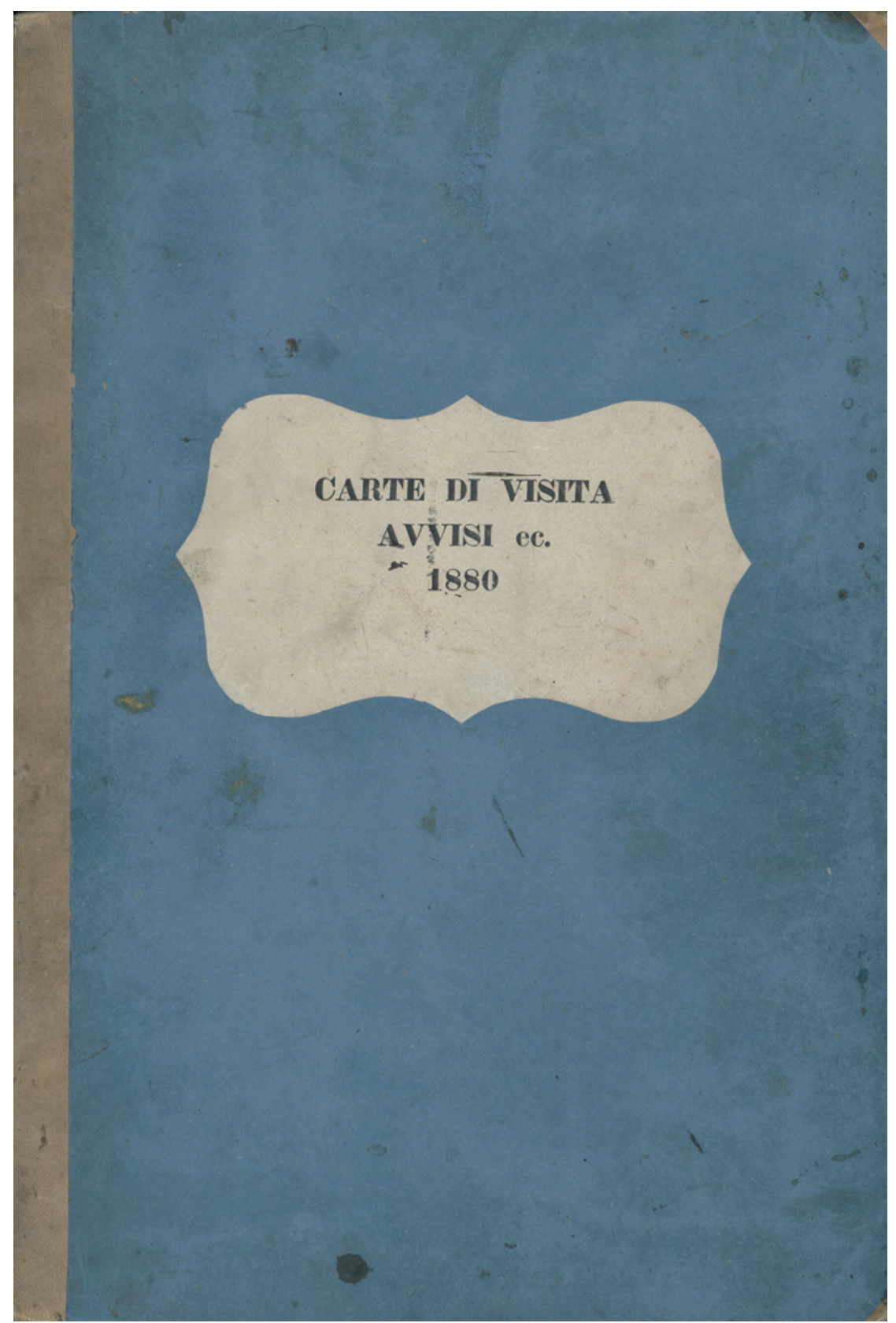

FIGURE 2.1 Cover of the catalogue "Carte di visita avvisi ec. 1880". 
cards had different purposes: to announce a visit, to inform others of a change of address, to invite people for a special occasion, or to make what was considered a polite gesture. They were tools in the hands of notabilities and the middle classes to create or strengthen networks of acquaintance. Cards were also used to convey the sender's regards on occasions such as weddings, births, and funerals. Trade cards were used to advertise shops and products, and they came in a variety of shapes and sizes.

The items listed above can be said to fall under the definition of "egodocuments" that testify to varied constructions of the self and its narratives, although visiting cards have not yet been studied as part of this category. ${ }^{10}$ These "printed ephemera" have traditionally been neglected by historiography. ${ }^{11}$ However, renewed attention to social, cultural, economic, and art history has contributed to the rediscovery of this material; a precious source for the study of material culture and consumption, ${ }^{12}$ design, etiquette between senders and recipients, social connections, and emotions. ${ }^{13}$ Nevertheless, the majority of case studies remains confined to Europe and the United States.

Linking the history of the FPP to the cards allows us to investigate a further aspect: the relevance of these materials to urban life and the connections between the city's inhabitants and the custodian publisher. The cards depict Jerusalemites crossing the gates of St. Saviour's convent to enter the FPP. This "history through names and surnames" provides a glimpse of the people living in the city and how they intended to present themselves. Comparing the cards reported in the album with the registries helps to describe the various landscapes of men and women, and the institutions and associations, that circulated around the FPP. The registries give further details about the characteristics of the cards themselves, their format, and their price. They report the name of the client, the type of object printed, their dimension expressed in

$10 \quad$ Ralf Elger and Yavuz Köse, eds., Many Ways of Speaking About the Self: Middle Eastern EgoDocuments in Arabic, Persian, and Turkish (14th-2oth Century) (Wiesbaden: Harrassowitz, 2010); Winfried Schulze, ed., Ego-Dokumente: Annäherung an den Menschen in der Geschichte (Berlin: Akademie, 1996).

11 For useful considerations on ephemera and historical narration, Mary-Elise Haug, "The Life Cycle of Printed Ephemera: A Case Study of the Maxine Waldron and Thelma Mendsen Collections," Winterthur Portfolio 30, no. 1 (1995).

12 See, for example, Maxine Berg and Helen Clifford, "Selling Consumption in the Eighteenth Century: Advertising and the Trade Card in Britain and France," Cultural and Social History 4, no. 2 (2007); Troy Bickham, "Eating the Empire: Intersections of Food, Cookery and Imperialism in Eighteenth-Century," Past \& Present, no. 198 (2008).

13 Barry Shank, A Token of My Affection: Greeting Cards and American Business Culture (New York: Columbia University Press, 2004). 


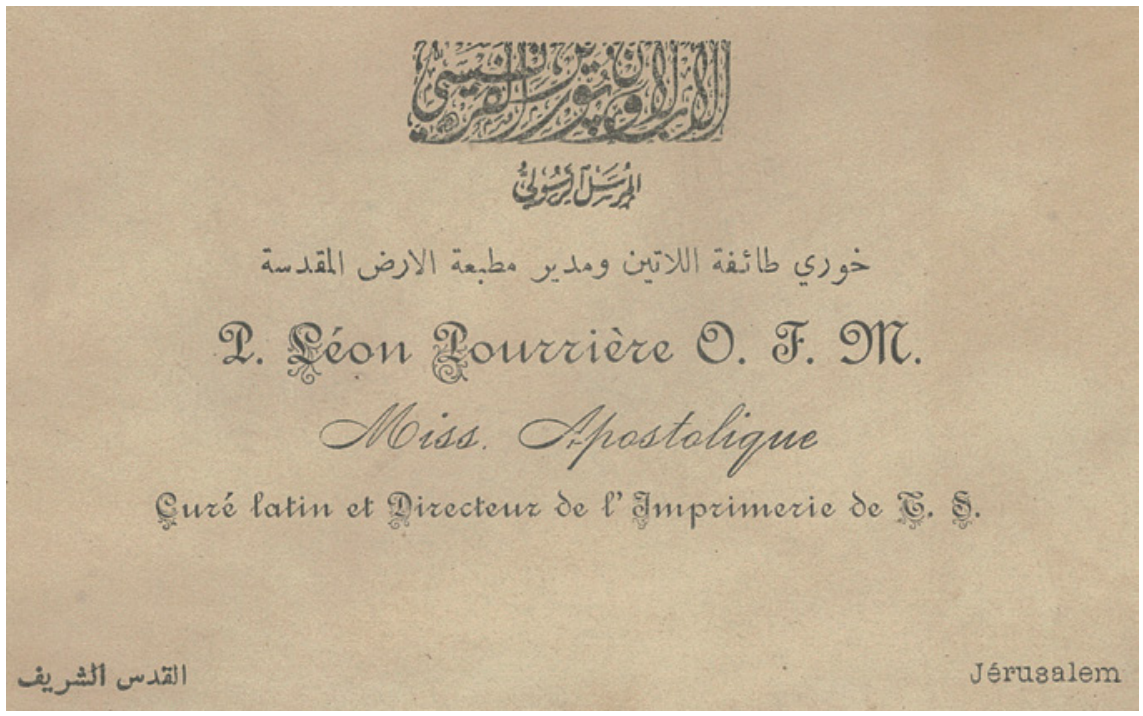

FIGURE 2.2 Visiting card of P. Léon Pourrière, OFM, ca. 1898.

"CARTE Di VISITA AVVISI EC. 1880," UNNUMBERED, 94.

sest $i$ - for visiting cards, usually 4, 8 and 16 sesti -14 their number, the binding (not included for cards), and finally, the price and date of delivery, sending and payment. The price, expressed in francs or local piastre, was affordable and permitted a wide circulation of these printed materials. ${ }^{15}$

Jerusalem business and calling cards generally reported the name, the title, and often (although not always) the profession of the person engraved in black ink at the center of the card (fig. 2.2). Decorative motifs, often with art nouveau influences, were sometimes added while blessings or holy images appeared on the cards of representatives of the Christian communities. Compared to coeval trade cards, the cards printed at the F PP still predominantly used words rather than images, though images appear in a few examples (fig. 2.3). Visual advertising culture was purveyed later and through different channels.

The album does not present the kind of photographic business and calling cards that circulated elsewhere in these decades showing the engraved name and a professional studio photograph of the person. However, studio

14 It was impossible to find out the exact dimension of sesto but generally the cards were $7.5 / 8 / 8.5 / 9.5 \mathrm{~cm} \times 4 / 5 / 5.5 / 6.5 \mathrm{~cm}$.

15 In 1900 the price of one hundred visiting cards was two francs. 


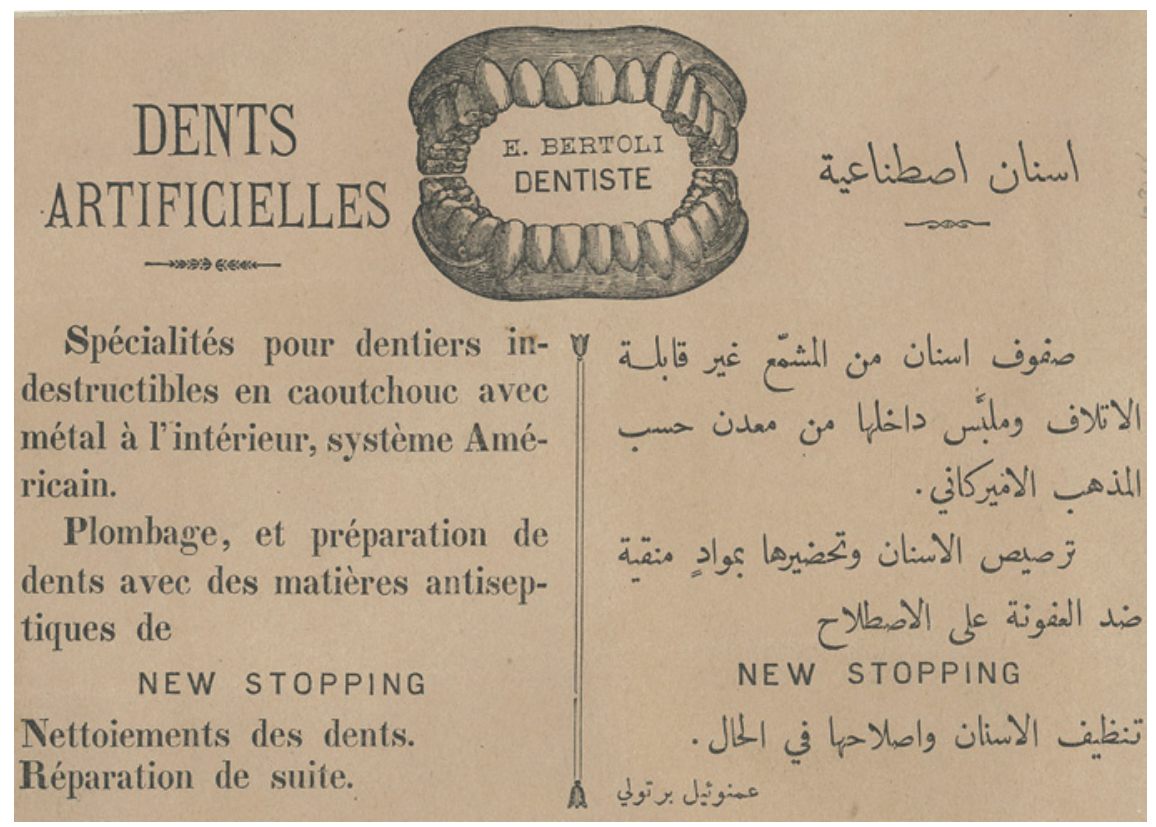

FIGURE 2.3 Visiting card of E. Bertoli, dentist, ca. 1894-95.

“CARTE Di Visita AVVISI EC. 1880," UNNUMBERED, P. 85.

photography was widely used in Jerusalem and the wider region at the time. ${ }^{16}$ Traditional nonphotographic cards remain unexplored. Therefore, the FPP objects can provide new insight into the construction, representation, and communication of Jerusalemites senses of the self in a phase of deep change.

The richness of this source relies on the number of the pieces, which is enough to give a relevant account of Jerusalem's bourgeoisie during a period in which the population of the city grew from 20,000 inhabitants in 1870 to 70,000 on the eve of World War I. The cards, which number around 1,500, are enough to test and even to validate research hypotheses. Moreover, these documents show that the Custody's publishing house was the city's de facto printing press.

16 Stephen Sheehi, "Portrait Paths: Studio Photography in Ottoman Palestine," Jerusalem Quarterly, no. 61 (2015), and Yair Wallach's chapter, "Reading the City, Writing the Self: Arabic and Hebrew Urban Texts in Jerusalem, 1840-1940," in this volume. 


\section{Urban Selves}

The governor of Jerusalem, the president of the municipality and its sitting members, the dragoman, the middleman, the banker, the shopper, the teacher, the shaykh of the mosque, the Jewish bookbinder, the Greek monk, the Druze chief, the young lady and her fiancé, the actress, the midwife, the artist, the engineer working on the Jaffa-Jerusalem railway, the pilgrim, the tourist ... all of these individuals flow through the pages of the catalogue in a "human comedy," testifying to the complexity and the vitality of the global city of Jerusalem. ${ }^{17}$ This gallery of inhabitants of and visitors to the city reveals their various social milieus, languages, civil statuses, occupations, religions, gender, and age, all reflecting a multifaceted and fascinating prism of citadinité. Each item adds a detail on the map of historical biographies, tracing new links between men, women, places, and spaces in the city and beyond.

Most of the cards are written in Latin characters, even Arab and Ottoman names. Around 15 percent of the cards use characters in the Arabic and/or Ottoman alphabets. Many cards are in French and English, while some are in Italian, German, Armenian, Spanish, Greek, Russian, Portuguese, Polish, Dutch, and even in Latin. Many pieces, especially business cards, combine two or three languages (often including errors), attesting to the linguistic diversity of the city at that time. Languages are sometimes linked to fonts: for example, German cards were habitually printed in Gothic fonts.

It doesn't come as a surprise to find, with certain titles of his transliterated according to French, the card of Sharif Mehmed Ra'uf Pasha [or Ch. M. Raouf Pacha on the card], ${ }^{18}$ governor of Jerusalem from 1877 to 1889; a key person in the history of the city as an Ottoman reformer, as well as that of Ibrahim Pasha [Ibrahim Pacha], mutessarif from 1890 to $1897 \cdot{ }^{19}$ The world of the Jerusalem municipality (baladīyya) appears in Salim al-Husayni's [Sélim el-Houseini and Sélim el-Husseini] calling cards as president of the municipality of Jerusalem (1882-97) (fig. 2.4), his successor Yassin al-Khalidi's [Yassine el-Khalidi] (18901901), as well as some municipal council members and secretaries of the city's government. ${ }^{20}$

17 Vincent Lemire, Jérusalem: Histoire d'une ville-monde des origines à nos jours (Paris: Flammarion, 2016).

18 The names on the cards are transliterated (according to IJMES) and are followed in brackets by the name as it appears on the card where a difference exists.

19 Vincent Lemire, Jerusalem 19oo: The Holy City in the Age of Possibilities, trans. Catherine Tihanyi and Lys Ann Weiss (Chicago: University of Chicago Press, 2017), 86-87.

20 At the turn of the century, among the members of the Jerusalem government whose cards were printed by the Franciscans was Negib Azoury [M. Azoury], a young Ottoman 


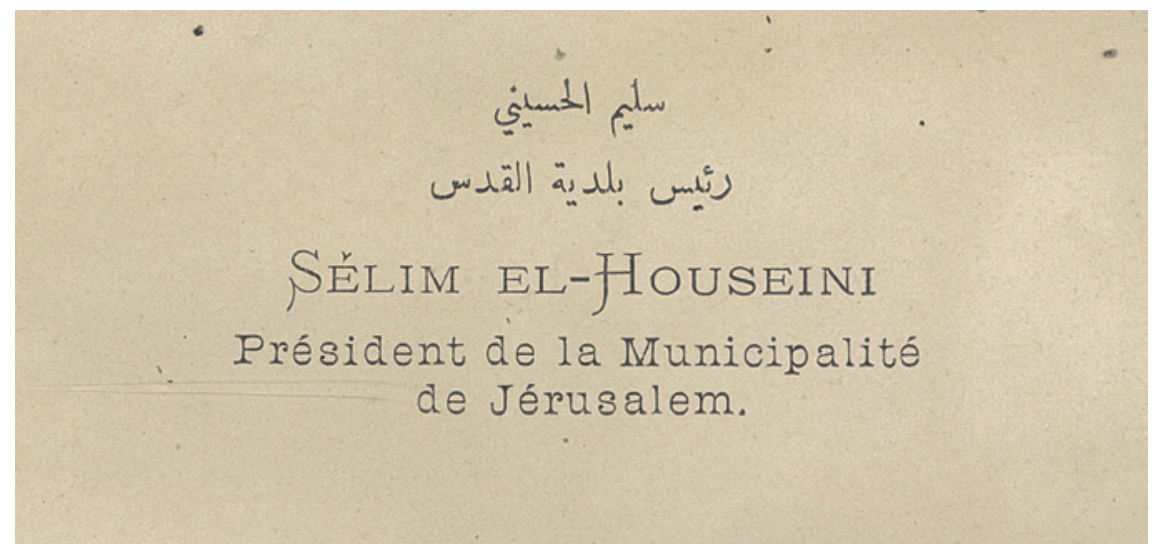

FIGURE 2.4 Visiting card of Salim al-Husayni, ca. 1889-9o.

“CARTE Di VISITA AVVISI EC. 1880, UNNUMBERED, P. 58.

Other representatives of the Ottoman administration had their cards issued by the FPP and these pieces attest to the introduction of new offices such as the Public Debt Administration, established in 1881, and the tobacco Régie after the establishment of the state monopoly on tobacco in 1874. Political modernization and technological innovations created brand-new roles and transformed already existing occupations: the electric telegraph reached Palestine in the middle of the 1860 s, and the calling cards of the telegraph and mail station chief in Bethlehem and Jaffa testify to their introduction. The governor's power is also symbolized by the gendarmerie, introduced during the Tanzimat period: 'Ali Bey [Aly Bey], major of the gendarmerie; Rustum Pasha [Rustem Pacha], general brigadier, and Rashid Bey [Rached bey], colonel of the infantry, used the FPP's services for their cards.

In this context of transformation, Jerusalem saw the birth of its Museum of Antiquities (1901), the first of four imperial museums conceived during the reign of Abdülhamid II to reinforce Ottoman power by linking it to the past (though not without reshaping it). ${ }^{21}$ Mahmud Şevket al-Khalidi [Mahmoud Chevket al-Khalidi] and Ibrahim Adham al-Khalidi feature among the inspectors of the museum. The construction of the imperial museum and new schools such as

official who, after leaving the city, would publish Le réveil de la nation arabe dans l'Asie turque (Paris: Librairie Plon, 1905), one of the first theorizations of Arab nationalism and anti-Zionism.

21 Beatrice St. Laurent and Himmet Taskömür, "The Imperial Museum of Antiquities in Jerusalem, 1890-1930: An Alternate Narrative," Jerusalem Quarterly, no. 55 (2013). 
the Ottoman lycée, whose teachers were clients of the FFP, are but examples of the rapid development of the city in the late nineteenth century.

The cards of Georgios Frangkias [Georges Franghia] and Olivero de Roccabigliera use the title of "Ingénieur en Chef de Palestine." The need to regulate and supervise urban growth pushed the municipality to create the position of chief engineer, a member of the municipal council. Georgios Frangkias, an Ottoman of Greek origin, contributed significantly to the city's transformation. ${ }^{22}$

The FPP recorded another crucial moment in the history of Jerusalem: the construction of the railway between Jaffa and the Holy City, completed in 1892. From 1890 on, the names of work superintendents, station chiefs, employees, accountants, technicians of the French company Société du Chemin de Fer Ottoman de Jaffa à Jérusalem et Prolongements, and the secretary of the imperial commissioner for the railroad, ordered their visiting cards in St. Saviour's convent. Bills of exchange (1891) (fig. 2.5) and the governor's invitation to the banquet celebrating the inauguration of the line, "le lundi, 26 septembre [1892], à 6 heures du soir," can be found among the cards. The Jaffa-Jerusalem railway construction had multiple and less obvious consequences, for example it permitted the opening, under the supervision of Dr. Fotios Efklidis [Photius Euclidès and Le Docteur Photios], of the municipal hospital (1891), ${ }^{23}$ access to which was free to all Jerusalemites. ${ }^{24}$ Efklidis' name appears among the FPP cards along with many other representatives of the medical milieu of the time. ${ }^{25}$

Glimpses into the world of entertainment can be caught as well. Examples include a ticket for a show by the illusionist Charles Reinhardt in the 188os, performances in August 1889 "in favor of the Municipal pharmacy," and a lottery for a sewing machine.

\footnotetext{
22 Lemire, La soif de Jérusalem, 306-7.

23 Johann Büssow, Hamidian Palestine: Politics and Society in the District of Jerusalem, 18721908 (Leiden: Brill, 2011), 529.

24 Zalman Greenberg, "The Turkish Municipal Hospital in Jerusalem and its Director Dr. Photios Efklides," in 38 . Uluslararası Tip Tarihi Kongresi Bildiri Kitabı. Proceedings of the 38 th International Congress on the History of Medicine. Actes du 38 . International d'Histoire de la Médécine, ed. Nil Sarı, Ali Haydar Bayat, Yeşim Ülman and Mary Işin (Ankara: Turk Tarih Kurumu, 2005).

25 Yaron Perry and Efraim Lev, Modern Medicine in the Holy Land:Pioneering British Medical Services (London: I. B. Tauris, 2007).
} 


\section{TRAVAUX DU CHEMIN DE FER DE JAFFA A JÉRUSALEM ET Pts}

Entreprise: FRANGHIA

Maconneries

(du Kil. 26 au Kil. 55)

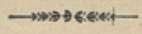

Bon pour

Veuillez payer au porteur nommé:

la somme de:

pour

Wady-Sarar le 1891

pour G. Franghia

\section{à $\mathbf{M}^{\mathrm{r}}$ Housseïn eff. el Housseёni}

FIGURE 2.5 Bill of exchange of the Société du Chemin de Fer Ottoman de Jaffa à Jérusalem et prolongements, 1891.

“CARTE Di VISITA AVVISI EC. 1880," UNNUMBERED, P. 70.

\section{Advertising the City}

Merchants, middlemen, and commercial entrepreneurs in Jerusalem widely patronized the FPP. Among them were Hayim 'Aharon Valero [H. A. Valero], representative of one of the most notable coalitions of Sephardi entrepreneurs in the city, ${ }^{26}$ consisting of Joseph Navon Bey, ${ }^{27}$ As'ad Kayat [Assad Kayat] (whose store's sign was inside Jaffa Gate), ${ }^{28}$ and 'Isa D. Katas [Eissa D. Gattas]. There were also representatives of foreign companies, such as Rafa'el Z. Kohen [Raphael Z. Cohen], who worked for Singer at a time when the sewing machine factory was expanding in the Middle East.

26 Joseph B. Glass and Ruth Kark, Sephardi Entrepreneurs in Jerusalem: The Valero Family, 1800-1948 (Jerusalem: Magnes Press, 2007).

27 Joseph B. Glass, "Biography in Historical-Geography Research: Joseph Navon Bey. A Case Study," in The Land that Became Israel: Studies in Historical Geography, ed. Ruth Kark (New Haven: Yale University Press; Jerusalem: Magnes Press, 1990).

28 Ayalon, Reading Palestine, 70. 
Among the main categories of people who used business cards extensively in Jerusalem and in the Ottoman Empire as a whole were the dragomans. ${ }^{29}$ Several dragomans were active in the city and had different functions and responsibilities. The registries and the cards reported their frequent visits to the FPP. Of these, dragomans serving as diplomatic interpreters between the European consuls, the Jerusalem government, and the Sublime Porte were the most important. The registries and the number of the ordered cards testify to their frequent visits to the FPP. Another class of client were tourist guides, who would sometimes also provide transport and accommodation. For example, the FPP printed business cards for the agents of Thomas Cook, pioneer of mass tourism in the nineteenth century, who had a branch in Palestine, as well as the tickets for their tours and many handbooks for Palestine and Syria, such as the famous Cook's and Baedeker's guides. Independent dragomans flourished in the city in these years. In their business cards, they highlighted their multilingualism and boasted, in a mix of French and English, that they were "natif of Jerusalem." They advertised their ability to "take private parties \& families on first class tours at a moderate price" and, in so doing, testified to the creation of a "language of success." 30

In the rising tourism industry, hotel owners also resorted to the use of business cards. In the 1880s, Jerusalem opened its first hotels following European standards and the Feil Hotel was the first to be erected outside the city walls. ${ }^{31}$ Its business cards signal that the hotel was furnished with "all the conveniences usually found in a first class hotel" and mention that the

29 On dragomans, guidebooks, tourists and pilgrims at this time, see Sarga Moussa, "Le sabir du drogman," Arabica 54, no. 4 (2007); Mark Mazower, "Travellers and the Oriental City, c. 1840-1920," Transactions of the Royal Historical Society 12 (2002); Bernard Heyberger, "Les nouveaux horizons méditerranéens des chrétiens du Bilād al-Šām (XVII ${ }^{\mathbf{e}}-$ XVIIII $^{\mathbf{e}}$ siècle)," Arabica 51, no. 4 (2004); Doron Bar and Kobi Cohen-Hattab, "A New Kind of Pilgrimage: The Modern Tourist Pilgrim of Nineteenth-Century and Early TwentiethCentury Palestine," Middle Eastern Studies 39, no. 2 (2003); Edmund Bosworth, "The Land of Palestine in the Late Ottoman Period as Mirrored in Western Guide Books," Bulletin (British Society for Middle Eastern Studies) 13, no. 1 (1986); Madiha Doss, "The Dragoman's Journey through Time and Space," Alif:Journal of Comparative Poetics, no. 26 (2006).

$30 \quad$ Natacha Coquery, "Language of Success: Marketing and Distributing Semi-Luxury Goods in Eighteenth-Century Paris," Journal of Design History 17, no. 1 (2004).

31 On the Feil Hotel and the dragomans in Jerusalem Rachel Mairs, From Khartoum to Jerusalem: The Dragoman Solomon Negima and His Clients, 1885-1933 (London: Bloomsbury, 2016), 192-93. 
hotel is "most conveniently situated for health and scenery."32 The cleanliness and the safety of these buildings were among the most common features boasted of on the cards, for example, the Damascus Hotel's owners, Alexander Howard and Morcos, ordered a bold-printed note saying "no pools or stagnant water around it," while Howard's Hotel opposite the Jaffa Gate (whose owner was the same Howard) asserted that "this Hotel has been constructed on the best Sanitary principles." Their insistence on cleanliness is consistent with the concern for the spread of diseases through water stagnation, which was frequently expressed in these decades by Jerusalem's inhabitants and authorities. The ambition to emulate European standards in order to attract Western clients is clearly reflected in the cards. The Damascus Hotel was equipped with a reading room with European and American newspapers, while the Howard's claimed to combine "the comforts of home with the luxury of the finest Hotels in Europe." The geography of tourism was another element and every card pointed out the major sites of interest near the hotels. Sites included the Damascus Gate, the Holy Sepulchre, the Mosque of Omar, as well as various consulates, and banks, thereby drawing a sort of religious, political, and economic sketch of the city.

The hotel cards printed by the FPP were mostly designed to serve the Western middle classes and haute-bourgeoisie. Other cards targeting tourists and pilgrims were those ordered by Jerusalemite shop owners. Through these cards, we can reconstruct a walk along the streets of the center city and its immediate surroundings, hearing the voices of the vendors quickly listing their products "at a moderate cost" to catch the attention of the foreign passersby. Objects of piety were the most common articles depicted on the cards, together with embroideries, photographs and lantern slides, mother-of-pearl, gold and silver, Dead Sea stone, old glass, pottery, coins, and other "Oriental articles illustrating Bible life \& history." Additional objects sold included flower cards, Bibles, manuscripts, and guidebooks. Most of the shop cards use varying typeface styles and sizes to highlight certain words. Some advertisements directly referred to the clients. ${ }^{33}$ In the pages of shop cards, we encounter Mitri Habib Kurt [Mitre Habib Kurt] in the Via Dolorosa and Y'aqub Marum [Jacob Marroum], Mantura Salah [Mantoura Salah] and Gabriel and Ibrahim Dabdub [Gabriel \& Abraham Dabdoub] near the Casa Nova. The renowned shop of

32 Shimon Gibson, Yoni Shapira and Rupert L. Chapman, eds., Tourists, Travellers and Hotels in 19th-Century Jerusalem (Leeds: Maney, 2013); Kobi Cohen-Hattab and Noam Shoval, Tourism, Religion and Pilgrimage in Jerusalem (New York: Routledge, 2015).

33 For example, A. Morcos and A. Abd-el-Messihi "Beg the travellers to the Holy Land to inspect their shop situated near the Jaffa Gate and the Greek Bazaar." 
Boulos Meo, situated very close to Jaffa Gate, was a distinctive part of the city landscape. Just beside Boulos Meo, under the Grand New Hotel, lay another important shop, the American Colony store, owned by Ferdinand Vester in what was then called "new Greek building." The various cards commissioned by Mr. Vester advertised that his collections had won "medals of merit" in recent universal exhibitions. Immanuel Berner, whose shop was beside the Hotel Fast near the Jaffa Gate, sold water from Jordon that he bottled himself as well as wines from the German settlements in Palestine. ${ }^{34}$ A few meters away, Ferdinando Nicodemo had his own shop. Nicodemo is an example of the "multiple selves" traceable through the FPP cards. The Franciscans printed several cards for him, each for a different profession and responsibility: he sold handicrafts and photographs, was a member of religious associations, and worked as dragoman for the Italian consulate in Jerusalem, which was very well-connected with the Catholic and Ethiopian Orthodox communities..$^{35}$ Nicodemo was one of the lay people living and working in the city who also belonged to religious congregations or groups (as in the case of the German Catholic workers' association, whose presence was revealed through pieces in the album), at the crossroad of economic, social, political, and religious worlds.

Tourists and pilgrims were not only recipients of business cards; they often had them commissioned for themselves. In the collection of the FPP, we find cards printed for travelers from France, Canada, and the United States. The predominance of French cards can be easily explained by the revival of pilgrimage in French culture after the war of $1870-71$ and the experience of the Paris Commune. ${ }^{36}$ Pilgrims' cards frequently presented the Jerusalem cross, then the name of the person and the year in which he/she visited the Holy Places, followed by their address in their country of origin. ${ }^{37}$ That a pilgrim

34 The Franciscan Custody complained that water from the Jordan river was being sold in bottles labeled "baptism water" and depicting an image of the Cross of the Holy Land. Archives of the Congregation for the Propagation of the Faith (ACPF), sC, Terra Santa e Cipro, vol. 24, ff. 650-51, Fra Serafino Milani to Card. Alessandro Barnabò, September 22, 1870.

The fonds of the Italian consulate of Jerusalem in the historical archives of the Ministry of Foreign Affairs in Rome has been recently inventoried by Costanza Lisi within the framework of Open Jerusalem project. See Roberto Mazza, Maria Chiara Rioli, and Stéphane Ancel, "The Italian Consulate in Jerusalem: The History of a Forgotten Diplomatic Mission, 1846-1940," Jerusalem Quarterly, no. 71 (2017).

36 Bertrand Lamure, "Le premier pèlerinage populaire de pénitence en Terre Sainte: L'ultime croisade," Bulletin du Centre de recherche français à Jérusalem, no. 14 (2004).

37 In 1901 Pope Leo XIII announced that every pilgrim to the Holy Land would be awarded a medal in bronze, silver or gold, depicting the Jerusalem cross, as a "signum sacri itineri 
could obtain a calling card during the pilgrimage to be shown and distributed upon arriving home shows how this tool was a way to state a sort of "pilgrim citadinité" in recognition of their voyage to the Holy City. Calling cards contributed to making the pilgrims inhabitants of Jerusalem in a way, although physically they were present for just a few weeks or months. The cards acted as symbols of this status.

Trade cards printed by the FPP were also in high demand outside of the tourist industry. Photographers often called on the services of the Franciscans to advertise their activities, and the cards bear witness to the new market which appeared at the end of the 1830 s. $^{38}$ Tancrède R. Dumas was an important artist who, like Felix Bonfils, had his studio in Beirut. Through his business card, we learn that during his stay in Jerusalem he worked for the German consulate, the American Palestine Exploration Society, and was a correspondent for L'Illustration. Luigi Fiorillo was an internationally known artist who mainly worked in Alexandria. He visited Jerusalem and the Holy Land between 1885 and 1887, documenting the work of the Franciscan friars who today preserve about 150 of Fiorillo's images in the Archivio Provinciale Aracoeli in Rome. Another well-known photographer at that time was Alexandre Gherardi, who had his studio just out of the Jaffa Gate. His business card relates his Catholic confession and his work photographing French pilgrims. The cards document other types of workers: sculptors, mercers, cabinetmakers, organ builders, potters, plasterers, saddlers, and upholsterers enrich the "census" of Jerusalemite craftsmen and artists of the period. The cards are mostly written in Italian and German, showing the origins of these workers and their client base.

\section{An Interfaith Printing Press?}

Predictably, a significant corpus of business cards belonged to teachers and theology professors of Christian schools and seminaries (Frères des écoles chrétiennes, Notre-Dame de Sion, St. Anne and others), and priests used their cards to solicit donations. In addition to this, it would seem that the FPP

hierosolymitani" (sign of the holy journey to Jerusalem). ACPF, NS, vol. 235, rubrica 126, ff. 387-403, Propaganda Fide to Patriarch Ludovico Piavi, 1902.

38 Walid Khalidi, Before Their Diaspora: A Photographic History of the Palestinians, 18761948 (Washington, DC: Institute for Palestine Studies, 1984); Badr al-Hajj, "Khalil Raad Jerusalem Photographer," Jerusalem Quarterly, nos. 11/12 (2001); Abigail Solomon-Godeau, "A Photographer in Jerusalem, 1855: Auguste Salzmann and His Times," October, no. 18 (1981). 


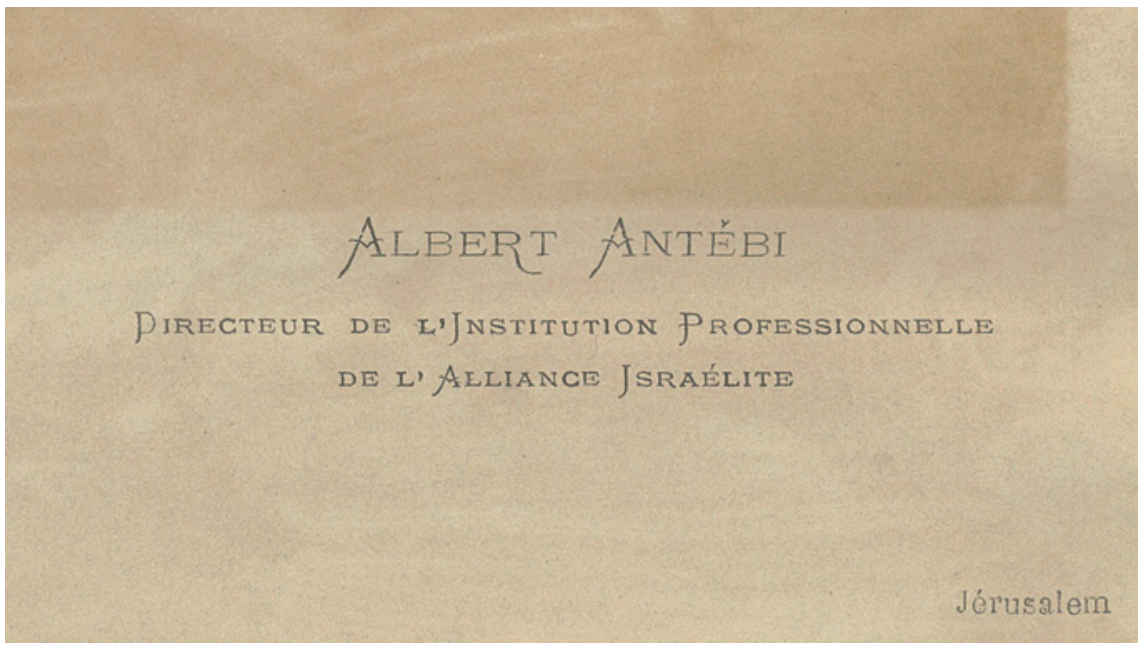

FIGURE 2.6 Visiting card of Albert Antébi, ca. 1898 .

“CARTE Di VISITA AVVISI EC. 1880," UNNUMBERED, P. 93.

functioned as an interfaith printing press patronized by Jewish intellectuals and Muslim chiefs. One finds the cards of prominent Sephardi Jewish Ottoman educators such as Nisim Bekhar [Nissim Behar] (1848-1931), and Albert Antébi (1873-1919) (fig. 2.6), the first two principles of the school of the Alliance Israélite Universelle (AIU) on Jaffa Road. ${ }^{39}$

Although visiting cards printed in Hebrew are scarce, the friars had close links with Jewish publishers. For example, the Franciscans sold machines and letter cases to Jewish bookbinders whose names recur several times in the registries. The same can be said for the AIU, which was a frequent client of the FPP at the turn of the century, as evidenced by the many books that the Franciscans printed and bound for them.

The interconfessional work by the FPP was attested in other publications. Jerusalem Rabbi Panigil's card (in French and Hebrew) and the invitation

39 On these two figures, see Alisa M. Ginio, Between Sepharad and Jerusalem: History, Identity and Memory of the Sephardim (Leiden: Brill, 2014), 138. On Antébi, see Elizabeth Antébi, L'homme du Sérail (Paris: Nil, 1996). On Bekhar and Ottoman citizenship, see Michelle U. Campos, Ottoman Brothers: Muslims, Christians, and Jews in Early Twentieth-Century Palestine (Stanford: Stanford University Press, 2011), 154, while on Antébi's anti-Zionism, see ibid., 218-20. Another important teacher of AIU Jerusalem school, Elie Astruc, printed his card at the FPP; Georges Weill, "Élie-Aristide Astruc, rabbin, écrivain et publiciste (Bordeaux, 12 décembre 1831-Bruxelles, 23 février 1905)," Archives Juives 35, no. 1 (2002). 
(only in French) to a circumcision ceremony hosted by the Amiel family on February $17,1889^{40}$ were among the papers issued by St. Saviour's convent. Printed materials, visiting cards in particular, were also a sort of "currency of exchange" for mutual respect and peace among religions. The FPP printed several books and other objects for free. Generally, these clients were Franciscan people or institutions, but in the registries we discover that the friars also issued visiting cards free of charge, as well as copies of the Qur'an and timetables of the Ramadan hours for the sheikhs of certain Jerusalem mosques. ${ }^{41}$ The cards seem to have been embedded within a system of favors to ensure stable relations between the custody and Islamic leaders in the city, particularly before the outbreak of World War I. ${ }^{42}$

Apart from Jewish Ottomanism and Muslim-Catholic relations, the FPP business cards and announcements are fascinating sources for the history of Christian millenarianism in nineteenth-century Palestine. Information on the Templers is particularly forthcoming. A vast catalogue of engagement and wedding announcements was printed by the machines at St. Saviour's. The names Hoffmann, Blankertz, Rockenbauch, Münzinger and Blenk are among the many Templer families in Jerusalem, Jaffa, and Sarona mentioned in the cards. ${ }^{43}$ The Templers' commercial activities are also documented. An example is Christian Fr. Eppinger (1833-1918), who made his living selling "Jerusalem's Wein." The Templer cross he chose to put on his card clearly attests to his identity and where he belonged within the city's mosaic of communities. ${ }^{44}$ The presence in Jerusalem - documented by his card, probably printed in 1883 - of François Vercruysse (1822-90), one of the forerunners of Christian Zionism, invites new paths of investigation: with whom was the author of Rénovation du monde in contact in the city? Did he come to promote and circulate his and his father's ideas on the return and conversion of Jews? ${ }^{45}$

\footnotetext{
40 ASCTs, "Introito attivo," oggetti stampati 1, January 2, 1888-December 22, 1894.

41 ASCTS, "Introito passivo," 1, January 1900-December 1908; January 1919-December 1919 "Libri ed oggetti dati o stampati gratuitamente 1900-1908 coll'aggiunta solo l'anno 1919." As far as I can tell from the registries, these public relations activities did not continue after 1918 .

43 On the Templers in Palestine, see Alex Carmel, Die Siedlungen der württembergischen Templer in Palästina, 1868-1918 (Stuttgart: Kohlhammer, 1973).

On Eppinger, see Helmut Glenk, From Desert Sands to Golden Oranges: The History of the German Templer Settlement of Sarona in Palestine, 1871-1947 (Victoria: Trafford, 2005).

François was the son of Dominique Joseph Vercruysse-Bruneel (1797-1880), Belgian author of La régénération du monde: opuscule dédié aux douze tribus d'Israël (Paris: Eugène Beyaert, 1860) and La résurrection dans le système de la régénération du monde: opuscule dédié aux douze tribus d'Israël (Brussels: Terneu, 1869). On these figures, see Yves
} 


\section{Portraits of Ladies}

The sketches of the population of Jerusalem that emerge from a study of business cards and announcements is at first sight a mostly male history. However, women do appear in different roles. Predictably, they are often recorded as wives and daughters of the diplomatic corps or other professionals (especially doctors or bankers, as in the case of Martha Frutiger of the Frutiger Swiss bankers), ${ }^{46}$ but there are also "couple's cards" in which the woman's name was more familiar in Jerusalem than the man's. This is the case for Mr. and Mrs. Sodar de Vaulx, from Belgium. Marie Sodar de Vaulx was the author of travel accounts ${ }^{47}$ and a book on the Holy Land ${ }^{48}$ which were widely circulated.

On occasion, women's names appear alone. They are mostly European superiors of female congregations running schools, hospitals or similar institutions. Less evident but more interesting is the small galaxy of women married, widowed, but more often single - whose names are linked to the launch of enterprises and who therefore ordered calling cards to publicize their activities. One such woman is "Mademoiselle de St. Cricq Dartigaux," who helped rebuild the Emmaus church after founding a Carmelite monastery in Bethlehem.

The registries report orders coming from many young French and Spanish women, especially in May, the Marian month which, according to Catholic tradition, marks the season of pilgrimage. Female pilgrims would therefore request their cards from the FPP in May, to mark the season. The most intriguing discovery in the Jerusalem's female universe as gleaned from these cards is the name of Ms. L. M. von Finkelstein (1855-1917). Born in Jerusalem, Finkelstein is still of uncertain origins. She may have been a Russian Jew who converted to Christianity or a Pentecostal religion. She was an eclectic actress and writer who became famous for her representations of the Bible all over the world, especially in the United States, where she spent many years. ${ }^{49}$ The FPP printed

Chevalier, "Quelques précurseurs chrétiens du Sionisme," in Aspects du Sionisme: théorie, utopie, histoire. Actes de l'atelier international INALCO tenu au Collège de France (Paris: INALCO, 1982).

46 Hans H. Frutiger and Jakob Eisler, Johannes Frutiger (1836-1899): Ein Schweizer Bankier in Jerusalem (Cologne: Böhlau, 2008).

47 Marie Sodar de Vaulx, Les splendeurs de la Terre Sainte, ses sanctuaires et leurs gardiens (Paris: Bloud et Barral, 1899).

48 Marie Sodar de Vaulx, Les gloires de Terre sainte, histoire de ses héros, de ses martyrs, de ses pèlerins (Paris: Bloud et Barral, 1899).

49 Burke O. Long, Imagining the Holy Land:Maps, Models, and Fantasy Travels (Bloomington: Indiana University Press, 2003), 22-25. 


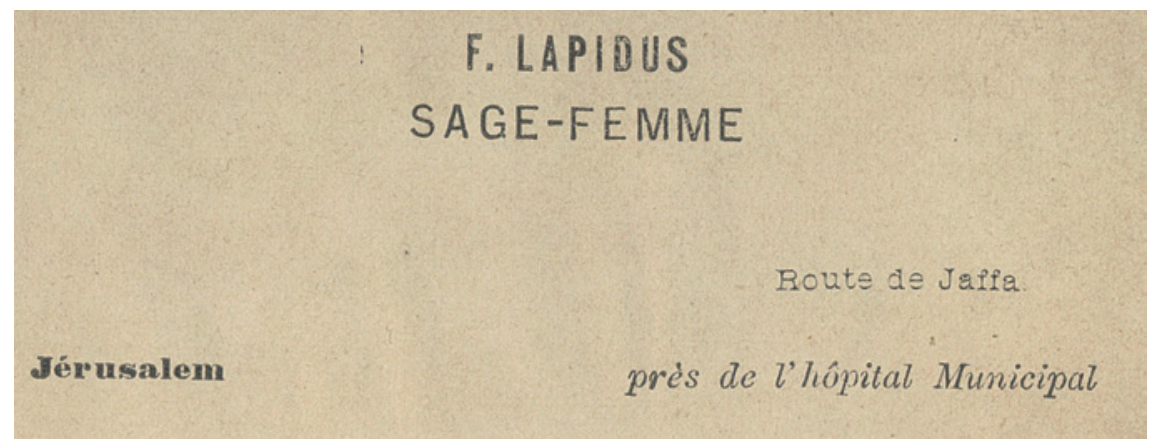

FIGURE 2.7 Visiting card of midwife F. Lapidus, ca. 1892-93.

“CARTE Di Visita AVVISI EC. 1880," UNNUMBERED, P. 75.

at least two versions of her card, with two different names. Printing the card of a nonauthorized performer of biblical interpretations, and a non-Catholic woman, shows the variety of city inhabitants and travelers who patronized the printing press at St. Saviour's. It also bears witness to the extent that women's freedom and self-initiative existed in Jerusalem at the time.

At least two midwives had their visiting cards printed at the FPP (fig. 2.7) ${ }^{50}$ For women, cards were not only a way to access various social circles, but were also used as tools to affirm their professional status and working capabilities. The desire to advertise their skills also indicates certain transformations in the job market. This stands in stark contrast to the harsh campaign pursued by Mandate authorities by which they attempted to control and restrict the activity of midwives in favor of the male British medical establishment, especially after the Midwives Ordinance of 1929 regulated the practice of midwifery. ${ }^{51}$ Concurrently, these decades saw a progressive professionalization of the medical field, with new regulations on hygiene and public sanitation implemented by Jerusalem's authorities. In a more competitive job market, where gender boundaries tended to grow more defined, midwives needed to make their job more visible in order to compete, rather than to confine their activity to the private sphere. This may suggest that other female service providers at the time did not need to declare their competences; they were acknowledged and

$5^{0}$ "F. Lapidus Sage-femme Route de Jaffa Jérusalem près de l'Hopital Municipal" and "Frumze Kestelmann Sage-femme Jérusalem."

$5^{1}$ Ellen L. Fleischmann, The Nation and Its "New" Women: The Palestinian Women's Movement, 1920-1948 (Berkeley: University of California Press, 2003), 243. 
circumscribed as performing exclusively female tasks, with no competition from male-dominated activities, especially in the countryside.

\section{Printed Voices of the City}

Life, time and space flow through the pages of the album. Reading the card for the Italian-Arab wedding of Martino Bertoli and Giulia Haddad, one may begin to imagine the relations connecting the families and communities of the bride and groom. Mourning times are also recorded. Many clients came to the friars to commission messages of condolence. The cards reflect birth and death, reveal the conjunction of public and private spheres, and the intersection of different professions, religions, and genders. The polyphony of these visiting cards attests to the richness of sources such as these, traditionally considered "ephemeral." Reconstructing the itineraries of the card owners is work that, in most cases, remains to be done.

What can already be clearly ascertained is that, together with other printed materials issued by the FPP, the proliferation of the visiting cards throughout Jerusalem allowed the friars to mark their presence in the city across different contexts. In light of this, these multilingual visiting cards must have been a powerful vehicle for social influence. The same card was often designed to be addressed to different recipients, as shown by Yassin al-Khalidi's card, where the languages bear witness to a varied set of targets (fig. 2.8): al-Khalidi's name

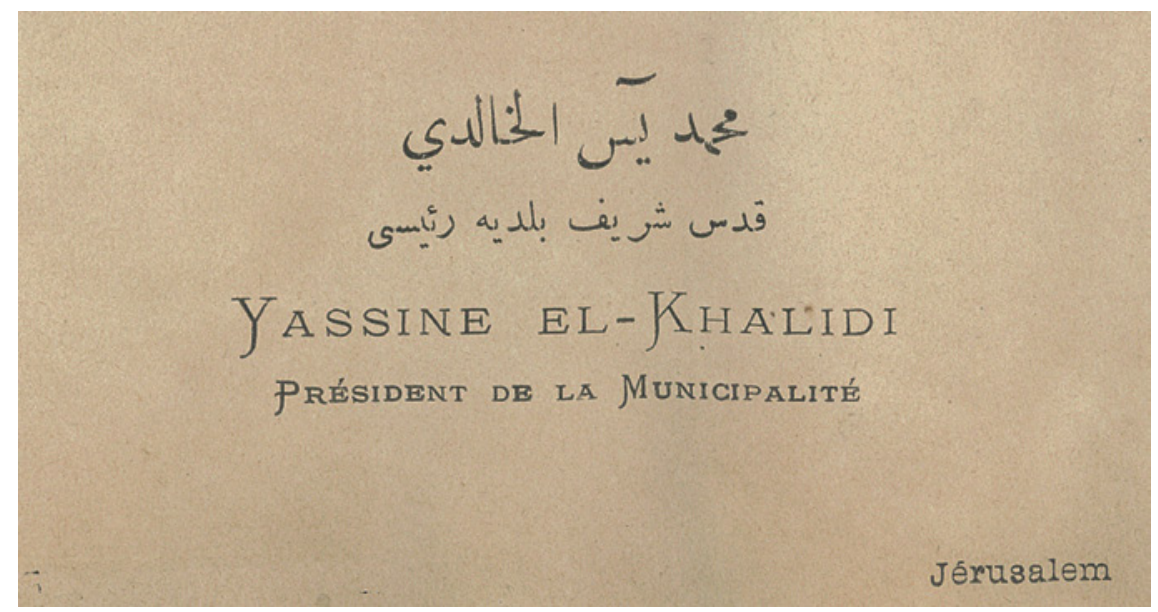

FIGURE 2.8 Visiting card of Yassin al-Khalidi, ca. 1898.

“CARTE Di VISITA AVVISI EC. 1880," UNNUMBERED, P. 91. 
is written in Arabic while his charge appears in Ottoman and in French, aiming at reaching, simultaneously but separately, Arab notables and people, Ottoman officials, and European diplomats and professionals. In a way, cards appear as both sectarian and nonsectarian tools, expressing relations within the communities (as in the case of the wedding cards), and to an even larger extent between them, retracing connections influenced by economic interests, social hierarchies, and religious messages.

Moreover, various other boundaries are redefined by these sources. A system of archival division wherein each section supposedly corresponds to a specific historical narrative now appears contradictory and limiting. Ecclesiastical archives reveal their nonconfessional patrimony, showing how religious sources and studies can contribute to general history, and, particularly, to urban history. Rescuing these books destined for the trash shows how the reclamation of abandoned sources can recast the definition of archives. Indeed, archives must sometimes leave the walls of institutions in order to expand the vast and unpredictable horizon of research possibilities open to historians.

This corpus of sources offers an exercise in microhistory. It is worth studying details such as the languages used and how they mixed, the order of the words, and the dimensions of the font on the cards. Furthermore, it is important to consider that in the same catalogue, at the same level, the card of the president of Jerusalem municipality and the card of an unknown midwife lay beside one another. Such observations provide opportunities to cross biographies, memories of the public self, codes of manner, ambitions and desires of social affirmation. In the end, the vast catalogue of objects printed by the FPP provides, as in a distorting mirror, ${ }^{52}$ an extremely vivid representation of daily life in Jerusalem; a nuanced and prismatic portrait made of "unconsidered or unnoticed details, from the rubbish heap." ${ }^{53}$

\footnotetext{
52 Ginzburg, History, Rhetoric, and Proof, 25.

53 This phrase by Sigmund Freud was quoted and adapted by Carlo Ginzburg in Myths, Emblems, Clues, trans. John and Anne C. Tedeschi (London: Hutchinson Radius, 1990), 99.
} 